\title{
IMPROVING THE CAPABILITIES OF STRATEGIC COMPETENCE AND MATHEMATICAL DISPOSITION USING THE INQUIRI MODEL OF ALBERTA METHOD
}

\author{
Supiyanto Supiyanto ${ }^{1}$, Heris Hendriana ${ }^{2}$, Rippi Maya ${ }^{3}$ \\ 1,2,3 IKIP Siliwangi, Jl. Terusan Jendral Sudirman Cimahi 40526 \\ ${ }^{1}$ soepieyanto@gmail.com, ${ }^{2}$ hendriana@ stkipsiliwangi.ac.id, ${ }^{3}$ rippimaya@gmail.com
}

Received: Aug 21 ${ }^{\text {st }}, 2018$; Accepted: Sep $8^{\text {th }}, 2018$

\begin{abstract}
This study aims first to improve the ability of strategic competencies and secondly to achieve mathematical dispositions in mathematical learning by using the Alberta model inquiry method and the third association between strategic competencies and mathematical dispositions. The subjects of this study are students of SMP class VII as many as two classes with a total of 64 students. The instruments used in data collection are written test of description for strategic competence and mathematical disposition and Alberta model inquiry method. The research used a quasi experiment. Data on strategic competence and mathematical disposition were analyzed using Mann Whitney nonparametric tests. The results of this study are: (1) Improvement of students' strategic competency skills whose learning method using Inquiry Model Alberta is better than the usual method; (2) The mathematical disposition of students whose learning method using the Inquiry Model Alberta is better than the usual method; (3) There is an association between the ability of strategic competence with mathematical disposition of students whose learning method using Inquiry Model Alberta.
\end{abstract}

Keywords: Strategic Competency, Mathematical Disposition, Alberta Model Inquiry Method.

\begin{abstract}
Abstrak
Penelitian ini bertujuan pertama untuk meningkatkan kemampuan kompetensi strategis dan kedua pencapaian disposisi matematik dalam pembelajaran matematik dengan menggunakan metode inkuiri model Alberta serta yang ketiga asosiasi antara kompetensi strategis dan disposisi matematik. Subjek dari penelitian ini siswa SMP kelas VII sebanyak dua kelas dengan jumlah 64 siswa. Instrumen yang digunakan dalam pengumpulan data adalah pretes postes. Metode penelitian yang digunakan adalah menggunakan kuasi eksperimen. Data kompetensi strategis dan disposisi matematik dianalisis dengan menggunakan uji nonparametrik Mann Whitney. Hasil penelitian ini yaitu: (1) Peningkatan kemampuan kompetensi strategis siswa yang mendapatkan pembelajaran dengan metode inkuiri model Alberta lebih baik dibandingkan dengan metode biasa; (2) Disposisi matematik siswa yang mendapatkan pembelajaran dengan metode inkuiri model Alberta lebih baik dibandingkan dengan metode biasa; (3) Terdapat asosiasi antara kemampuan kompetensi strategis dengan disposisi matematik siswa yang pembelajarannya menggunakan metode inkuiri model Alberta.
\end{abstract}

Kata Kunci: Kompetensi Strategis, Disposisi Matematik, Metode Inkuiri Model Alberta.

How to Cite: Supiyanto., Hendriana, Herris., \& Maya, Rippi. (2018). Improving The Capabilities Of Strategic Competence And Mathematical Disposition Using The Inquiri Model Of Alberta Method.JIML, 1 (3), 218-224. 


\section{INTRODUCTION}

In the early stages of mathematics is formed from human experience in the empirical world. Then the experience is processed and processed by analysis with reasoning in the cognitive structure so that it comes to a conclusion of mathematical concepts. In order for mathematical concepts that have been formed to be understood by everyone, and can be easily manipulated precisely, careful notation and terminology are made through a global agreement, which became known as the mathematical language (Suherman, 2001).

Ruseffendi (Suherman, 2001) suggests that mathematics is a structured science organized. That's because learning from a mathematical element that is not defined, then continues on the elements that are defined, axiom or postulate and ends in the theorem. Meanwhile, according to Johnson and Rising (Suherman, 2001) mathematics is a pattern of thinking, organizing patterns, and logical proof. Still, according to Johnson and Rising, mathematics is a language that uses precisely defined, clear, accurate, and symbolic representations, and emphasizes the symbolic language of ideas rather than sounds.

Based on the mathematical characteristics as stated above, then the mathematical learning in the school should prepare the condition of the students to be able to master the concepts that will be studied from the simplest to the more complex. The purpose of mathematics learning in schools according to MoNE (2007) is to understand the concept of mathematics, explaining the interrelationship between concepts, using reasoning on patterns of nature, solving problems, communicating ideas, and having an attitude of appreciating the usefulness of mathematics in life.

In relation to the desired learning objectives in mathematics, Sumarmo (Hulukati, 2005) suggests that mathematical learning in essence has two directions of development that is to meet the needs of the present and the future. The present need in question is that mathematical learning leads to an understanding of the concepts necessary to solve other mathematical and scientific problems. That is, the need in the future is a mathematical learning that provides logical, systematic, critical, and careful logical and objective thinking and open-minded thinking. In this case the ability is very necessary in everyday life as well as to face the ever-changing future.

Wood et al.(Laswadi, 2015) also stated that the potential of mathematics as a science has the opportunity to raise awareness of social problems and change society for the better. Thus, mathematical skills are potential human resources that must be developed in order to advance the nation. The mathematical skills developed by (Kilpatrick, J., Swafford, J., \& Findell, 2001), namely: conceptual understanding, procedural fulency, strategic competence, adaptive reasoning, and productive disposition.

Based on the above explanation of the objectives of mathematics learning and the potential of mathematical skills, in this case the authors intend to focus on research on mathematical strategic competence is the ability of students in formulating, representing, and solving mathematical problems (Kilpatrick, J., Swafford, J., \& Findell, 2001). While mathematical disposition is a tendency to view mathematics as plausible, to regard mathematics as something useful and valuable, to believe that a persistent effort in learning mathematics is not a waste, and to see oneself as an effective mathematical learner as well mathematician (Kilpatrick, J., Swafford, J., \& Findell, 2001).

However, based on preliminary study in one of junior high school students' mathematical competence is still low. It is proven when the author doing observation of learning in the class, students tend to 
memorize mathematical formulas that have been given, so that when teachers give different problems with the same concept, the students have difficulty. The authors suspect that the mathematical strategic competencies held by students are still low. This is because when learning in the classroom students accept only mathematical concepts, not by finding out themselves about the concept of mathematics.

Then the authors also found the low of mathematical significance for students. At the time of learning in the classroom some students there are complaining, bored, drowsy, so they do not pay attention to learning. Observing this condition, the authors suspect that students do not have a positive attitude towards mathematics or mathematical productive disposition. Though mathematics has a very close relationship with everyday life, such as shopping, trading, designing buildings, and banking activities.

In the cognitive development of students, there are two factors that affect the internal and external factors Ruseffendi (Syah, 2010). One of them is teacher activity in creating learning process which can give opportunity to student to actively participate in teaching and learning process, so that there is motivation in student to learn. This is supported by NCTM (Aisah, 2015) who argue that the practice of mathematical learning is shifting from teacher centered learning to student centered learning, and transforming students who were formerly passive learners into learner learners active (active learners). This is as (Wahyudin, 1999) argued that the ability of mathematicians to use various methods or approaches appropriately and correctly in teaching can influence the level of mastery of students in the mathematics itself.

\section{Theoretical Review}

\section{Strategic Competence}

Mathematical strategic competence is the ability to formulate, represent, and seek solutions to mathematical problems (Kilpatrick, J., Swafford, J., \& Findell, 2001). In other literatures, mathematical strategic competence is also called problem solving ability. Furthermore, (Kilpatrick, J., Swafford, J., \& Findell, 2001) suggests that the mathematical problems that teachers provide to students in schools are often quite clear, both given conditions and what needs to be resolved. But outside of school, students are faced with problems that are not easy to formulate as a mathematical problem. For example, the student must manage the allowance given by his parents so that the money can meet all the needs with certain circumstances. Such problems require students to formulate problems as mathematical problems studied in schools and determine what has been known and what to look for. As a consequence, according to (Kilpatrick, J., Swafford, J., \& Findell, 2001) they need to have experience and practice in formulating the problem from a particular situation to a mathematical problem.

The ability of students in solving mathematical problems is influenced by the readiness to use the competencies already owned, otherwise experience in solving problems can help students learn new mathematical concepts.

As for this research indicator of mathematic strategic competency refers to indicator which have been developed by (Laswadi, 2015) that is:

a. Formulating the problem becomes a mathematical problem.

b. Represents the problem.

c. Solve problems using correct concepts and procedures.

\section{Mathematical Disposition}

Mathematical dispositions show: 1) Confidence in using mathematics, solving problems, giving reasons and communicating ideas; 2) flexibility in investigating mathematical ideas and trying to find alternative methods of problem solving; 3) diligently doing mathematical tasks; 4) interest, curiosity and inventiveness in performing mathematical tasks; 5) tend to monitor, reflect on their own performances and reasoning 6) assess mathematical applications of other situations in 
mathematics and daily experience; 7) appreciation of mathematical roles in culture and values, mathematics as a tool and as a language, (Polking J, 1998)

The scale of mathematical disposition used is by adapting the scale developed by (Kesumawati, 2010). The scale is chosen because the subject Kesumawati research has the same characteristics with this study, namely junior high school students. The mathematical disposition scale developed by Kesumawati includes the following indicators:

1. Confident in solving mathematical problems, communicating ideas and giving reasons.

2. Flexible in exploring mathematical ideas and trying different methods to solve problems.

3. Determined to complete mathematical tasks.

4. Interest and curiosity to find something new in doing mathematics.

5. The tendency to monitor and reflect on thinking and performance processes. Apply mathematics in other fields and in everyday life.

6. Award of mathematical roles in culture and values, both mathematics as a tool, and mathematics as a language.

\section{The Alberta Model Inquiry a Learning Method}

That involves students actively in the process of investigation or problem solving through several stages of planning, retrieving, completing, creating, sharing and sharing, and evaluating. Learning by the Inuit Model Alberta method provides students the opportunity to develop the skills they will need throughout their lives, learn to deal with problems that may not have clear solutions, changes and challenges of the times, and guide investigations to find solutions at this time and in the future (Alberta, 2004). Then Kuhlthau(Alberta, 2004) argues that learning by inquiry methods can develop students' cognitive and affective abilities. This is related to the findings of the author based on preliminary studies in the field that is about strategic competence and mathematical productive disposition. Therefore, based on these issues, the authors are interested in conducting research on the stages in Alberta's inquiry learning of the Alberta model (Alberta, 2004) consist of planning, retrieving, processing, creating, sharing, and evaluating.

\section{METHOD}

This study is a quasi experimental research because in this study subjects were not grouped randomly, but researchers accept the state of the subject as it is (Ruseffendi, 2005). The use of the research design is done with the consideration that the class has been formed before, so no random grouping is done anymore.

This study was conducted on students of two classes who had equivalent mathematical abilities. The first group was given a mathematical lesson using the inquiri model Alberta method. The first group is an experimental group, while the second group is a control group that obtains mathematical learning with the usual method of expository.

The given treatment is in the form of mathematical learning using the Inquiri Model Alberta method to see its effect on the measured aspect, that is the strategic competence and mathematical productive disposition of the students.

Table 1. Research Design Patterns

\begin{tabular}{|c|c|c|c|c|}
\hline & Class & Prerespone & Treatment & Postrespone \\
\hline $\mathbf{S}$ & & & & Strategic \\
\hline U & & & Mathematical & Competency Test \\
\hline $\begin{array}{l}\text { B } \\
\text { E } \\
\text { C }\end{array}$ & Experiments & $\begin{array}{l}\text { Strategic } \\
\text { Competency Tests }\end{array}$ & $\begin{array}{l}\text { learning with the } \\
\text { Inquiry Method of } \\
\text { Alberta Model }\end{array}$ & $\begin{array}{l}\text { Questionnaire } \\
\text { Mathematical } \\
\text { Disposition }\end{array}$ \\
\hline
\end{tabular}




\begin{tabular}{llll}
\hline \multirow{3}{*}{ Control } & Strategic & Mathematical & Strategic \\
& Competency Test & $\begin{array}{l}\text { Competency Tests } \\
\text { usual methods }\end{array}$ & \\
\cline { 3 - 4 } & & & $\begin{array}{l}\text { Questionnaire } \\
\text { Mathematical } \\
\text { Disposition }\end{array}$ \\
\hline
\end{tabular}

The design in this study is pretest-postes(Ruseffendi, 2005) as follows:

Control Class :

$\mathrm{O} \quad \mathrm{O}$

Information :

$\mathrm{O}_{1}$ : Pretes $=$ Postes

$\mathrm{X}$ : Mathematical learning by the Inquiry Method of Alberta Model

-----: Subjects are not randomly grouped

The population of this study is junior high school students in Cimahi City academic year 2017/2018. With the sample subjects are class VII students of two classes as control class and experiment class. The research instrument used in collecting test data. The form of the test is essay or about the form of description with the number of 5 questions of strategic competence and for the mathematical disposition used attitude scale with the number of 30 questions.

\section{RESULTS AND DISCUSSION}

\section{Scale Analysis Strategic Competence}

Pretest and postes scale were analyzed to find out the mean and gain index. The result of descriptive analysis is presented in the following table:

Table 2. Data Processing Results Mathematical Strategic Competency Ability Test

\begin{tabular}{|c|c|c|c|c|c|c|c|}
\hline \multirow{2}{*}{ Variabel } & & \multicolumn{3}{|c|}{ Inquiry Method Alberta model } & \multicolumn{2}{|c|}{ Ordinary Learning } & \multirow[b]{2}{*}{ N-Gain } \\
\hline & & Pretest & Postest & N-Gain & Pretest & Postest & \\
\hline \multirow{4}{*}{$\begin{array}{l}\text { Strategic } \\
\text { Competency } \\
\text { (SMI 50) }\end{array}$} & $\mathrm{N}$ & 32 & 32 & 32 & 32 & 32 & 32 \\
\hline & $\overline{\mathrm{x}}$ & 16,08 & 26,75 & 0,31 & 14,22 & 22,94 & 0,24 \\
\hline & $(\%)$ & 32,16 & 53,50 & & 28,44 & 45,88 & \\
\hline & $\mathrm{S}$ & 12,64 & 8,73 & 0,19 & 11,69 & 8,44 & 0,18 \\
\hline
\end{tabular}

Based on the data in Table 2, the standard deviation for pretest mathematical strategic competencies in the class that gets learning with Alberta model inquiry method is higher than the one that gets ordinary learning, meaning that in the class that receives Alberta model inquiry method learning, the initial ability of mathematical strategic competence is more diffuse than the class. who get regular learning.

\section{Analysis of Mathematical Productive Disposition Questionnaire}

Pretest and postes data were analyzed descriptively to find out mean and gain index, this is done to see the quality of learning. The results of descriptive analysis are presented in the following table:

Table 3. Mathematical Disposition Scale Data Processing Results

Variabel Inquiry Method Alberta model Ordinary Learning




\begin{tabular}{lccccccc}
\hline & & Pretest & Postest & N-Gain & Pretest & Postest & N-Gain \\
\hline \multirow{2}{*}{$\begin{array}{l}\text { Disposition } \\
\text { Mathematics }\end{array}$} & $\mathrm{N}$ & - & 32 & - & - & 32 & - \\
\cline { 2 - 8 } & $\overline{\mathrm{x}}$ & - & 76,81 & - & - & 71,19 & - \\
\cline { 2 - 8 } & $(\%)$ & - & 64,01 & - & - & 59,33 & - \\
\cline { 2 - 8 } & $\mathrm{S}$ & - & 10,32 & - & - & 10,04 & - \\
\hline
\end{tabular}

In Table 3, for the data the average mathematical disposition of students who get learning with the Alberta model inquiry method and the ordinary learning class is relatively the same, with high criteria. This means that the two classes have relatively high mathematical dispositions. For standard deviations of class mathematical dispositions with the Alberta model inquiry method higher than ordinary learning classes. This means that in classes that are learning the Alberta model inquiry method, their mathematical dispositions are more diffuse than those that use ordinary learning.

\section{Association Analysis between Strategic Competence and Mathematical Productive Disposition}

Posttes result scale of strategic competence and final data of mathematical productive disposition were analyzed to see the assosiation between the two. Based on Chi-Square test results obtained in the following table:

Table 4. Chi Square Test Results Ability of Strategic Mathematical and Disposition Competencies

\begin{tabular}{lccc}
\hline & Value & df & Asymp Sig (2-side) \\
\hline Pearson Chi-Square & $5.338^{\text {a }}$ & 4 & .025 \\
Likelihood Ratio & 6.407 & 4 & .171 \\
Linear-by-linear Assosiation & .348 & 1 & .555 \\
N of Valid Cases & 32 & & \\
\hline
\end{tabular}

a. 6 cells $(66.7 \%)$ have expected count less than 5 . The Minimum expected count is 1.25

Based on Table 4 with a significance level of 0.05 , a sig value of $0.025<0.05$ was obtained. It can be concluded that there is a significant association between mathematical strategic competencies and mathematical dispositions

\section{CONCLUSION}

Based on the results of the analysis and discussion that have been described in the previous Chapter, there are some things that the authors conclude, namely:

1. The improvement of students' mathematical strategic competence ability which get the mathematical learning with Inquiry method of Alberta model is better than the students who get the mathematical learning with the usual method.

2. Improvement in mathematical productive disposition of students who obtain mathematical learning by the method of Inquiry Model Alberta is better than students who get mathematical learning with the usual method.

3. There is a significant association between mathematical strategic competencies and mathematical dispositions 
224 Supiyanto, Hendriana \& Maya, Improving the Capabilities of Strategic Competence and

Mathematical Disposition Using the Inquiri Model of Alberta Method

\section{REFERENCES}

Aisah, L. S. (2015). Mathematical learning based on didactic phenomenon through scientific approach to improve the ability of mathematical connection and self-esteem of junior high school students. (Thesis). Graduate School, University of Education Indonesia, Bandung.

Alberta. (2004). Focus on inquiry: a teacher's guided to implementing inquiry-based learning. Edmonton. AB: Alberta Learning.

Hulukati, E. P. (2005). Developing communication skills and problem solving of junior high school students through generative learning model. (Dissertation). Graduate School, University of Education Indonesia, Bandung.

Kesumawati, N. (2010). Peningkatan KemampuanPemecahan Masalah dan Disposisi Matematis Siswa SMP Melalui Pendekatan Matematika Realistik. Disertasi UPI Bandung Tidak di terbitkan.

Kilpatrick, J., Swafford, J., \& Findell, B. (2001). Adding it up: helping childern learn mathematics. Washington, DC: National Academy Press.

Laswadi. (2015). Develops the mathematical skills of junior high school students through a modelfacilitated-learning (MFL) approach. (Dissertation). Graduate School, University of Education Indonesia, Bandung.

Polking J. (1998). Respons To NCTM's Round 4 Questions,. https://doi.org/[Online] Tersedia: http//www.ams.org/government/argrp14.html. [18 Maret 2017]

Ruseffendi, H. E. T. (2005). Fundamentals of research \& other non-exact areas. Bandung: Tarsito.

Suherman, et al. (2001). Contemporary mathematical learning strategy. Bandung: JICA FPMIPA UPI.

Syah, M. (2010). Educational Psychology. Bandung: Remaja Rosdakarya.

Wahyudin. (1999). Kemampuan Guru Matematika, Calon Guru Matematika dan Siswa Dalam Mata Pelajaran Matematika. Disertasi UPI Bandung. 